\title{
INTER ARMA ENIM SILENT LEGES \\ (IN TIMES OF WAR, THE LAWS FALL SILENT) VIOLENCE IN MEDIEVAL WARFARE
}

\author{
Andrzej Niewiński \\ The John Paul II Catholic University of Lublin \\ Military and Historic Laboratory \\ Katolicki Uniwersytet Lubelski Jana Pawła II \\ Pracownia Wojskowo-Historyczna \\ niewin@kul.pl
}

\begin{abstract}
The present paper addresses the subject of military violence in the Middle Ages. The medieval chroniclers and writers provide numerous instances of wartime atrocities and massacres of non-combatants and prisoners of war. The attempts to place restraints on the conduct of war were undertaken by the Church as early as in the 11th century. It has been examined how these efforts together with the code of chivalry, royal ordinances and the writings of ius in bello theorists influenced soldiers' behaviour and whether they were instrumental in reducing civilians suffering. The conclusion has been reached that despite all the endeavours to limit arms violence it basically remained unmitigated.
\end{abstract}

Keywords: violence, warfare, Middle Ages, ius in bello, prisoners of war

The endemic character of warfare in the Middle Ages seems to imply general acceptance of the status quo. People fought, killed and suffered. However, the need arouse, as early as in 4th century, to answer the question whether Christians are allowed to fight and how military engagement can be justified ${ }^{1}$. The atrocities of war went somehow contrary to human sensitivity, common sense, and Christian religion; on the other hand, warfare was generally accepted as the traditional solution of various conflicts and regarded even as an instrument of restoring peace and justice $^{2}$. Medieval canonists and theologians, from Isidore of Seville until St. Thomas

1 The most notable example is Augustine's De civitate Dei upon which Gratian and other proponents of the just war theory drew heavily.

2 Honoré Bouvet, the Benedictine monk and author of L'arbre des batailles written towards the end of the fourteenth century, criticized violence (especially that directed against non-combatants) but he also saw it as a just punishment inflicted by God. Since God allowed war in order to punish men for their sins, the gens d'armes were regarded as "les exécuteurs de nostre Seigneur", the flail of 
Aquinas, generally cited Augustinian principles in the matter of military activities ${ }^{3}$. The two main principles regarding ius in bello were that of proportionality and of discrimination. Gratian's Decretum, written in the 12th century, was a comprehensive compilation of canon law drawing on the accumulated traditions of the Church from apostolic times. In the causa 23 of his Decretum Gratian deals with moral limits to war, exempting (according to the principle of discrimination) from the ravages of war certain classes of persons: clerics, pilgrims, travellers, merchants, peasants, women, and unarmed poor, which can be regarded as an attempt to define non-combatants immunity ${ }^{4}$. His treatment of with this aspect was, however, somewhat superficial and confined to only passing references to the idea that some groups of people should be immune from looting and pillaging and that the use of armed force should be limited to actions deemed necessary ${ }^{5}$.

Church's effort at restraint of violence was expressed in the two major peace movements known as Peace of God (declared in the late 10th century by French bishops) and Truce of God (originated in Italy in 11th century). What is more, the Second Lateran Council banned the use of crossbows ${ }^{6}$. These were the first systematic attempts to define and protect the status of non-combatants, to put restraint on violence at least on the holiest Christian days. In practice the non-combatant immunity guaranteed by the Peace of God to all clergy, women, children, the aged, agricultural workers, and the poor was not more effective than the Truce of God's declarations that Christians could only attack other Christians between Monday morning and Thursday evening, except during Advent and Lent, when they could

God. War was seen as a way of restoring peace, a medicine to restore health, and if it sometimes oppressed the good and the just, it was for the increase of their glory. The tree of battles of Honoré Bonet, trans. and ed. G.W. Coopland, Liverpool 1949, p. 157-158.

3 Augustinian doctrine, formulated within the framework provided by Cicero, involved theses of necessity of war as an instrument of peace and order, as well as the conditions under which just war should be waged. These outline become the model for later scholastics and medieval jurists to develop.

${ }^{4}$ F.H. Russell, The just war in the Middle Ages, Cambridge 1975, p. 70. This principle is mirrored in the chronicle accounts: all chroniclers, on all sides, draw attention to the same sorts of abuses perpetrated by men-at-arms. It was generally thought despicable to kill the following categories of people: children (especially infants), women, elderly, and clerics. Spoliation of churches and church property was also widely condemned. So was the infliction of deliberate or ostentatious cruelty (mutilation, rape). The sameness of the chroniclers perception as to what was considered to be atrocious sometimes makes it difficult to establish what had really happened and what is rendering a template. See A. MaCDOnALD, Two kinds of war? Brutality and atrocity in later Medieval Scotland, in: Killing and being killed. Bodies in battle. Perspectives on fighters in the Middle Ages, ed. J. Rogge, Bielefeld 2017, p. 205.

5 A.J. Bellamy, Just wars. From Cicero to Iraq, Cambridge 2006, p. 37.

6 J.T. Johnson, Just war tradition and the restraint of war. A moral and historical inquiry, Princeton 2014, p. 124. 
not attack them at all. Nevertheless, these movements made a very significant contribution to the formulation of the laws of war in western Europe ${ }^{7}$.

Medieval chronicles, however, testify extensively to the fact that Augustinian teaching, Church doctrine, and canon law did not have much influence on standard military practice of the ordinary men-at-arms ${ }^{8}$. The limited observance of these regulations (which, additionally, were not sufficiently specific) frequently made them practically valueless. War lost nothing of its atrociousness. Armed attacks constantly brought fear and terror to non-combatants, as the following examples will show.

Pitched battles were generally avoided in the Middle Ages. The most popular tactics of warfare were sieges, skirmishes, and destructive raids, known as chevauchées. Such raids were large-scale campaigns of devastation which involved pillaging, burning and indiscriminate killing. Armies routinely pillaged towns, attacked non-combatants, took what they could carry and burned the rest ${ }^{9}$. Their main aim was thorough destruction of countryside in order to inflict substantial damage to the adversary in the shortest time possible ${ }^{10}$. Terrorizing and massacring villagers was a standard modus operandi in numerous situations - not only during the Hundred Years War (when this tactic gained the greatest popularity) but also during the English-Scottish wars (Scottish riding of northern England was recurrent and systematic, resembling very much the later English tactic in France), or when some rebel lords tried to oppose the king. In the early 12th century one of the most infamous raiders was Robert of Belleme who, among many other gruesome deeds, burned a church with 45 people inside ${ }^{11}$. A chevauchée as the instrument of pressure was widely used in the times of William Marshal - the word is actually employed by the History of William Marshal. It was also the kind of war the best English knight principally fought - a war full of ravaging and violent destruction ${ }^{12}$.

7 R.C. StACEY, The age of chivalry, in: The laws of war. Constraints on warfare in the western world, ed. M. Howard, G.J. Andreopoulos, M.R. Shulman, New Haven 1994, p. 29.

8 J. Gilchrist, The papacy and war against the 'Saracens', 795-1216, "The International History Review", 10(1988), No. 2, p. 178.

9 T.R. SMITH, Willing body, willing mind. Non-combatant culpability according to English combatant writers 1327-77, in: Killing and being killed..., p. 79-107.

${ }^{10}$ This strategy, also called a war of attrition, was advocated by late fourth century Roman writer Vegetius (whose treatise De re militari was widely known and extremely popular in the Middle Ages) due to its effectiveness and minor risks to the attacker. See C. Allmand, The 'De re militari' of Vegetius. The reception, transmission and legacy of a Roman text in the Middle Ages, Cambridge 2011.

${ }^{11}$ L.W. Marvin, Atrocity and massacre in the high and late Middle-Ages, in: Theatres of violence. Massacre, mass killing and atrocity throughout history, ed. Ph. Dwyer, L. Ryan, New York-Oxford 2012, p. 57.

${ }^{12}$ D. Crouch, William Marshal. Knighthood, war and chivalry, 1147-1219, Routlege 2014, p. 204. 
Jean de Venette, the French chronicler appalled by the devastation and atrocities of warfare, wrote in 1358:

Losses and injuries were inflicted by friend and foe alike upon the rural population and upon monasteries standing in the open country. Everyone robbed them of their goods and there was no one to defend them. For this reason many men and women, both secular and religious were compelled on all sides to leave their abode and seek out the city [...] there was not a monastery in the neighbourhood of Paris, however near, that was not driven by fear of freebooters to enter the city or some other fortification, abandoning their buildings and, "Woe is me!" leaving the divine offices unsung. This tribulation increased in volume, not only around Paris but also in the neighbourhood of Orléans, Tours, Nantes in Brittany, Chartres, and Le Mans, in an amazing way. Villages were burned and their population plundered. Men hastened to the cities with their carts and their goods, their wives and their children, in lamentable fashion ${ }^{13}$.

The chevauchée became the main English strategy in France ${ }^{14}$ during the Hundred Years War. In addition to financial consequences, it struck a mighty psychological blow and undermined the morale of the enemy's army. Violence and ferocity of these technically legitimate attacks were undistinguishable from that of feuds that were regarded as private, illegitimate wars (as different from the just war fought for a just cause $)^{15}$.

The so-called grande chevauchée led by the Black Prince in Languedoc in 1355-1356 resulted in ferocious ravaging and plundering of the whole country ${ }^{16}$. It was destructive, extremely brutal, yet also methodical and well planned. The prince marched from Bordeaux to the Mediterranean coast and back, fighting only a few minor skirmishes. Over 500 villages were burned, the villagers were robbed and murdered. Only religious buildings and the lands of the count of Foix

${ }^{13}$ The chronicle of Jean de Venette, ed. and trans. J. Birdsall, R.A. Newhall, New York 1953, p. 75-76. See D. Green, The Hundred Years War. A people's history, New Haven 2014.

${ }^{14}$ English raids were reciprocated by French - the chroniclers Thomas Walsingham and John Froissart describe the terrible French raid on the south coast near Lewes in 1377 which resulted in ransacking and burning of the whole town together with some small villages nearby. Contemporary chronicles of the Hundred Years' War, ed. and trans. P.E. Thompson, London 1966, p. 176-177.

${ }^{15}$ Distinguishing between the legitimate and illegitimate conflict was not, however, a simple matter in his Coutumes de Beauvaisis (written in the second half of the 13th century) the jurist Philippe de Beaumanoir accepted the right of the nobility to wage private war, although with caveats which included that a conflict could not be between individuals within four degrees of kinship, and that certain people were exempt from private war including clerks, those who had entered religion, women, children, and those in leper-houses and hospitals. See R.E. Whitbread, Tournaments, jousts and duels. Formal combats in England and France, circa 1380-1440, University of York 2013, p. 117.

${ }^{16}$ H.J. HewitT, The Black Prince's expedition of 1355-1357, Manchester 1958; D. Whetham, Just wars and moral victories. Surprise, deception and the normative framework of European war in the later Middle Ages, Leiden 2009. 
were spared ${ }^{17}$. What is more, the actions of the Anglo-Gascon army effectively convinced the people of Languedoc that the French king and his lieutenants could not protect them from the English. Some historians are of the opinion that the systematic destruction of countryside employed by the Black Prince was a strategic device aimed at provoking the French into battle ${ }^{18}$. The strategy proved to be successful as it was followed by the English victory at Poitiers in 1356. However, the greatest losses were suffered by non-combatants.

Prisoners of war were another category, alongside non-combatants, to be spared. In the Middle Ages it was fairly well developed custom not to kill captives who surrendered to their captors ${ }^{19}$. Again, their fate could have been different. Some prisoners, taken for ransom, were successfully freed afterwards, some of them were enslaved or set free even without ransom, but not all of them had a chance to stay alive - mass killings of prisoners were not uncommon in the Middle Ages.

Richard I the Lionheart, the king traditionally regarded as a true model of knight and warrior, infamously killed roughly 2700 Muslim prisoners ${ }^{20}$ at Ayyadieh, after the siege of Acre in 1191. Why did it happen? There is no unanimous explanation of this heinous deed due to impossibility of establishing who exactly (Richard or Saladin) did not honour the terms of agreement according to which Saladin was to pay ransom and to return the True Cross that had fallen into his hands after the battle of Hattin ${ }^{21}$. It may have happened that the negotiations collapsed when the first instalment of the ransom became due, as Saladin had not made payment ${ }^{22}$, or that Richard's expectations were not met by the agreed ransom scheme and his anger got the better of him. The killing could have also been an answer to Saladin's massacre of the Templars and Hospitallers after Hattin in $1187^{23}$ or else, a deliberate act meaning that Richard's goal never was to take

${ }^{17}$ D. GreEn, The Black Prince, Stroud 2008, p. 76.

${ }^{18}$ C. TAYLOR, Chivalry and the ideals of knighthood in France during the Hundred Years War, Cambridge 2013, p. 210.

${ }^{19}$ As Matthew Strickland points out, the custom of taking prisoners for ransom, though widespread, was in no way obligatory - the captives could have been killed, tortured or mutilated depending on the complex blend of military, political and personal considerations. Cf. M. STRICKLAND, War and chivalry. The conduct and perception of war In England and Normandy 1066-1217, Cambridge 1996, p. 53.

${ }^{20}$ The number of prisoners is confirmed in the Itinerarium peregrinorum et gesta regis Ricardi, an anonymous account of Richard I's deeds on crusade.

${ }^{21}$ For different views see J.D. HosLER, The siege of Acre, 1189-1191. Saladin, Richard the Lionheart, and the battle that decided the Third Crusade, Yale 2018.

22 J. Riley-Smith, The crusades. A history, New Haven 2005, p. 144.

${ }^{23}$ Slaughter of prisoners can be understood in terms of punishment or precautionary measures. In 1179 the whole garrison (700 Templars) of Jacob's Ford (Vadum Jacob) were slain, the rest 
prisoners. However, it may be true that after a month, when Saladin still did not pay the ransom and showed no intention to abide by the terms agreed, the prisoners became more a burden than an asset and Richard may have been pressed for time as he wanted to move on. In his letter to the abbot of Clairvaux Richard merely says that "the time limit expired and, as the treaty to which Saladin had agreed was entirely made void, we quite properly had all the Saracens that we had in custody [...] put to death" ${ }^{\prime 2}$.

Somewhat surprisingly, the execution of Muslim captives, widely condemned by modern historians, was not regarded by the contemporary Christian writers as a barbarous and entirely reprehensible deed. Richard I, being an expert at military strategy, could neither wait indefinitely at Acre, nor take the prisoners with him or simply free them (it would have given Saladin an upper hand and undermine Richard's authority in his army). It seems that his contemporaries understood (if not exactly approved) the military advantages gained by slaughter of prisoners ${ }^{25}$. William of Breton was of the opinion that Richard's anger was just. Geoffrey de Vinsauf reports that Saladin not only failed to return the True Cross, but deliberately tried in a number of ways to cause delay. According to Baha ad-Din, a Muslim eyewitness to the Third Crusade who was in the service of Saladin, it was these delays that made Richard I to change his mind ${ }^{26}$.

However, the same Richard in 1183, after his victory at Gorre, drowned, beheaded, and blinded ${ }^{27}$ his prisoners (who were routiers hired by the leader of insurgents, viscount of Limoges). He also is known to have blinded his prisoners in 1198 while fighting the French king Philip in Normandy. On the other hand, Philip blinded English prisoners after his defeat near Gisors, where he had been attacked

enslaved. Some of them were Turcopoles, recruited from converted Muslims. It could have been intended by Saladin as an act of punishment. Similarly, after the battle of Hattin, Saladin had put to death all the captured Templars and Hospitallers, without negotiating any options of ransom.

${ }^{24}$ J. Gillingham, Richard I, New Haven 1999, p. 168.

${ }^{25}$ Ibidem, p. 170.

${ }^{26}$ J. Stroik, The massacre at Acre - mark of a bloodthirsty king?, "Oshkosh Scholar", 5(2010), p. 32. Baha ad-Din, Massacre of the Muslim prisoners, in: Arab historians of the crusades, ed. F. Gabrieli, New York 1993, p. 131-132, 223-224.

${ }^{27}$ The Anglo-Norman combination of blinding and castration as a substitute of death penalty was an established practice from the approximately 11th century and is mentioned in the Chanson de Guillaume written in Normandy in the mid-twelfth century. In 1188 count Raymond of Toulouse, upon entering into war against Henry II and Richard the Lionheart, captured Poitevin merchants and then blinded and castrated some of them, while killing the others. See E. WheatLey, Stumbling blocks before the blind. Medieval constructions of a disability, Michigan 2014; K. VAN EICKELS, Gendered violence. Castration and blinding as punishment for treason in Normandy and Anglo-Norman England, "Gender \& History", 16(2004), No. 3, p. 588-602. 
by surprise and tried to retreat which resulted in many casualties ${ }^{28}$. Prince John in 1194 beheaded captured French knights ${ }^{29}$. The Scottish warrior James Douglas, one of Robert Bruce's foremost commanders, is known as the Black Douglas to the English for his numerous atrocities committed during the Scottish Wars of Independence. In 1307, after having attacked the English garrison in the attempt to retake family castle, he beheaded the prisoners and threw the bodies into the castle where they were burned. Douglas also mutilated some captured English archers by cutting off their hands before setting them free ${ }^{30}$.

Violence often had a symbolic dimension to it, being instrumental in emphasizing the message. Mutilation and visual torture was often imposed on those regarded as traitors. The earl of Atholl, who joined Robert the Bruce in rebellion against Edward I, was hanged on a gallows despite his elevated status. He was subsequently let down (still alive) and beheaded, his body was burnt and his head placed on London Bridge ${ }^{31}$. Symbolic violence was enacted, for example, on the remains of Hugh Cressingham, the hated representative of Edward I in Scotland, killed at the battle of Stirling Bridge: he was flayed and his skin cut into tokens which circulated among the Scottish host as remainders of victory ${ }^{32}$.

In the 14th century, after the battle at Halidon Hill (1333) Edward III ordered all the prisoners to be killed ${ }^{33}$. Abbot Thomas Burton adds in his chronicle that on the day after the battle the king ordered 100 prisoners to be beheaded ${ }^{34}$. Scottish

${ }^{28}$ Violence mounted as a result of previous hostilities: according to Roger of Howden Philip burnt in 1198 twenty-five Norman towns, while Richard's favourite routier Mercadier, known for his ruthlessness, plundered Abbeville fair, killing numerous French merchants. R. BROOKs, The knight who saved England. William Marshal and the French invasion, 1217, Bloomsbury 2014; F. McLynn, Lionheart and Lackland. King Richard, king John and the wars of conquest, London 2006, p. 269270.

${ }^{29}$ M. STRICKLAND, War and chivalry..., p. 52.

${ }^{30}$ A. Macdonald, Two kinds of war?, p. 199-230. It is worth mentioning that such treatment of prisoners was not always the case. The good example is Sir Thomas Gray, the constable of Norham castle: captured by the Scots in 1355, he was imprisoned in Edinburgh Castle for two years. There he must have been treated well enough to be given access to the library and archives which made it possible for him to compile the chronicles of Great Britain later called Scalacronica. A. KING, War and peace. A knight's tale. The ethics of war in Sir Thomas Gray's Scalacronica, in: War, government and aristocracy in the British Isles, C.1150-1500. Essays in honour of Michael Prestwich, ed. Ch. Given-Wilson, A. Kettle, L. Scales, Woodbridge 2008, p. 148-162.

${ }^{31}$ J.G. Bellamy, The law of treason in England in the later Middle Ages, Cambridge 2004, p. 46.

${ }^{32}$ A. Macdonald, Two kinds of war?..., p. 214.

33 I.A. MacInnes, Scotland's second war of independence 1332-1357, Cambridge 2016, p. 191.

${ }^{34}$ A. GRANSDEN, Historical writing in England c. 1307 to the early sixteenth century, London 1982, p. 358-360; A. KING, 'Then a great misfortune befell them'. The laws of war on surrender and the killing of prisoners on the battlefield in the Hundred Years War, in: Agincourt in context. War on land and sea, ed. R. Ambühl, C. Lambert 2018, p. 106-117. 
chronicler Andrew Wyntoun reports that on the day after the battle many of the English disobeyed Edward's orders and some of them saved their prisoners out of pity ${ }^{35}$. The battle itself was fierce and caused many casualties: Scots were severely wounded and blinded by the English archery. Later on the uncoordinated charge resulted in disoriented flight, while a strong press of bodies of people trying to escape led to numerous deaths on both sides. Killing of prisoners in this context may seem superfluous.

No contemporary source offers any explanation for Edward's actions. It is possible that the prisoners were executed as traitors to Edward Balliol, regarded by the English as the rightful king of Scots. On the other hand, Edward III might have decided that no prisoners should be taken ${ }^{36}$.

John of Portugal killed his prisoners at Aljubarrota, the battle that ended Castile's invasion of Portugal in 1385. The execution was prompted by renewed attack of Castilian army which might have given prisoners the chance to escape and become dangerous. According to Froissart, over 300 prisoners were killed, although they could have brought even 400,000 francs in ransoms. These killings were regarded as a safety measure necessary to protect the winning party - it was agreed that the imprisoned enemy could not be trusted. On the other hand, Froissart reports a somewhat contradictory account of the battle given to John of Gaunt by a Portuguese envoy:

The king commanded on pain of death by beheading that no-one should hold anyone to ransom
that day if we were victorious; either all were to die or all live. This instruction was for the
best since, as the lords said, "If we were to occupy ourselves in taking prisoners, we would
become distracted and not pay due attention to what we should be doing. It is better for us to
concentrate on fighting well, rather than succumb to an avaricious desire to take prisoners,
and give it our all as good men must do whose heritage is at stake". This pronouncement was
accepted and adhered to ${ }^{37}$.

Another massacre of prisoners took place after the disastrous battle of Nicopolis (1396) where the allied crusader army was defeated by Ottoman Turks under the leadership of Bayezid I. Franco-Burgundian attack was unsuccessful due to their leaders unwillingness to act accordingly with the suggestions of the Hungarian

${ }^{35}$ The original chronicle of Andrew of Wyntoun, vol. 6, ed. F.J. Amours, 1903, p. 12.

${ }^{36}$ According to the chronicle The deeds of Edward III, composed by the canons of Bridlington, lord Archibald Douglas, the Scottish leader at Halidon Hill, had proclaimed before the battle that no prisoners and no ransom should be taken. The wars of Edward III. Sources and interpretations, ed. and introduction C.J. Rogers, Woodbridge 1999.

${ }^{37}$ A. KING, 'Then a great misfortune befell them'..., p. 111; C. TAYLOR, Chivalry and the ideals..., p. 204. See also J. Gouveia Monteiro, The battle of Aljubarrota [1385]. A reassessment, in: The age of the Hundred Years War, ed. C.J. Rogers, K. DeVries, J. France, Woodbridge 2009 (Journal of Medieval Military History,7), p. 75-103. 
king. Turks' counterattack was damaging. Those who could tried to flee from the battlefield. Those who could not were doomed. Accustomed to the protection of ransom, Franco-Burgundian soldiers were given no chance but killed without mercy. Western chroniclers claimed that the Turks executed thousands of Christian prisoners, including knights and nobles ${ }^{38}$. Some of them were taken prisoners only to be decapitated or to die as a result of a severing their limbs from the body. Part of the prisoners were put into servitude. Only the richest and the noblest (among them John the Fearless) were spared and subsequently ransomed ${ }^{39}$.

Henry V had executed almost all the French prisoners after the battle of Agincourt in 1415. The author of the Gesta Henrici Quinti who, by his own account, was present there at the time, describes attempts by Frenchmen to surrender:

Indeed, fear and trembling seized them, for, so it was said among the army, there were some of them, even of their more nobly born, who that day surrendered themselves more than ten times. No one, however, had time to take them prisoner, but almost all, without distinction of person, were, as soon as they were struck down, put to death without respite, either by those who had laid them low or by others following after, by what secret judgment of God is not known ${ }^{40}$.

The French chronicler Enguerrand de Monstrelet describes how the duke of Alençon engaged in a fight with Henry V, trying subsequently to surrender but succeeding only in making himself an easy target:

Seeing that he could not escape death, [he] lifted his hand to the king of England and said "I am the duke of Alençon and surrender myself to you". But just as the king was ready to take his oath, he was quickly killed by the king's bodyguard ${ }^{41}$.

English and French accounts alike generally try to explain the killing of the prisoners in terms of military necessity - Henry is reported to have been alarmed

${ }^{38}$ Muslim chroniclers presented these executions as an act of retaliation by Sultan Bayezid I for the massacre of Muslims' and Orthodox Christians' by crusader knights. See K.L. DeVRIES, The lack of a western European military response to the Ottoman invasions of Eastern Europe from Nicopolis (1396) to Monies (1526), in: Medieval warfare 1300-1450, ed. K.L. DeVries, Ashgate 2010, p. $417-$ 440.

${ }^{39}$ Idem, The effect of killing the Christian prisoners at the battle of Nicopolis, in: Crusaders, condottieri, and cannon. Medieval warfare in societies around the Mediterranean, ed. L.J. Andrew Villalon, D. Kagay, Leiden 2002, p. 157-172.

${ }^{40}$ Gesta Henrici Quinti. The deeds of Henry the Fifth, ed. F. Taylor, J.S. Roskell, Oxford 1975, p. 91; A. CuRrY, The battle of Agincourt. Sources and interpretations, Woodbridge 2000, p. 37.

${ }^{41}$ La chronique d'Enguerran de Monstrelet, t. 3, ed. L. Douët-d'Arcq, Paris 1859, p. 119-120. Duke Alençon's attempt to surrender is discussed by A. Curry, Agincourt. A new history, Stroud 2005, p. 258-259. 
by the arrival of the duke of Brabant which posed a threat of a new attack by the French. The king could not afford the risk. On the other hand, after the prisoners had been killed, there was no further action; there was even no rout as French cavalry had withdrawn earlier. Was there a real danger? It is also true, however, that Henry had to move quickly after the battle which gave no room for a large amount of booty and prisoners.

It is significant that no French source explicitly criticizes Henry for his actions. The Burgundian chroniclers Jean le Fèvre and Jean de Wavrin comment that it was "a pitiable matter", but put the blame on a "wretched company of the French who had caused the death of these noble knights"42. Jean Juvénal des Ursins, the archbishop of Reims, explains the execution matter-of-factly: "[...] the French rallied themselves, which was a great misfortune, for most of the English killed their prisoners"43. Killing of prisoners was not, therefore, regarded as violation of the laws of war.

The conquest of a besieged city or town often ended in brutal massacres of civil population. In July 1099, after the siege lasting five weeks, the crusaders took Jerusalem and three days later slaughtered all the inhabitants, making no distinction between age, gender, or religious affiliation ${ }^{44}$. Some of them had been captured, but were killed the next day. It has been argued that the killing resulted from religious zeal - the desire to exterminate pagans - but it was more a precaution against the possible change of balance, an effort to retain the advantage. Albert of Aachen in his Historia Ierosolimitana makes the point clear:

[...] but now we must be careful lest we lose it through avarice or sloth or the pity we have for our enemies, sparing prisoners and gentiles still left in the city. For if we were to be attacked in great strength by the king of Babylon we should be suddenly overcome from inside and outside the city, and in this way carried away into external exile ${ }^{45}$.

However, the cruelty of massacre was outrageous and probably unnecessary ${ }^{46}$. Fulcher of Chartres, who arrived in Jerusalem a few months later, witnessed the

${ }^{42}$ A. KING, 'Then a great misfortune befell them'..., p. 110; A. CURRY, The battle of Agincourt..., p. 164.

${ }^{43}$ Jean Juvénal des Ursins, Histoire de Charles VI, roy de France, in: Nouvelle collection des mémoires pour servir à l'histoire de France, 1st series, vol. 2, ed. J.F. Michaud, J.J.F. Poujoulat, Paris 1836, p. 519; A. King, 'Then a great misfortune befell them'..., p. 112.

${ }^{44}$ L.W. Marvin, Atrocity and massacre..., p. 55.

${ }^{45}$ Albert of Aachen, Historia Ierosolimitana. History of the journey to Jerusalem, ed. and trans. S.B. Edgington, Oxford 2007, p. 441. Cf. Y. Friedman, Encounter between enemies. Captivity and ransom in the Latin Kingdom of Jerusalem, Leiden 2002, p. 18.

${ }^{46}$ Another example of unmitigated cruelty reported by the chroniclers is the conquest of Ma'arrat al Nu'man (1098), where the crusaders killed everyone and ripped up the bodies of the dead in hope to find some gold coins in their entrails or cut the flesh and cooked it to eat. Ibidem, p. 19. 
terrible aftermath of the slaughter. He reported that no one survived apart from the Fatimid governor and his retinue, who managed to surrender to Count Raymond ${ }^{47}$.

In 1296, during the Scottish wars, the English army sacked Berwick. The slaughter continued for two days. Thousands of people were killed (mostly non-combatants), their bodies "fell like autumn leaves" and, as there was no one to bury them, thrown down wells or into the sea ${ }^{48}$. Even the churches did not save the inhabitants. Though Scottish historians have tended to view this as a particularly appalling atrocity, behind this massacre lay a perfectly understandable and practical reason. Edward I intended to show to the Scots the consequences of resistance Berwick refused to surrender when given a chance ${ }^{49}$.

The systematic devastation (known as herschip, or harrying) of Buchan, a district in northern Scotland ruled by clan Comyn, is another example of particular brutality. It was inflicted in 1308 by Robert the Bruce who wanted to destroy support for his rival, John Comyn. The whole earldom was laid waste and depopulated, everything was destroyed and burned. The remarkable fact about Buchan was that these atrocities were carried out not by the English but by the Scots against their fellow countrymen ${ }^{50}$.

The Albigenses Crusade is generally considered as a particularly ruthless war due to harsh treatment of captives and non-combatants. According to the chronicles the heretics were regarded by crusaders as worse than Saracens; on the other hand, the Albigenses were as fierce as their opponents. There was mass mutilation of prisoners, knights killed and quartered, or dragged by the tails of horses and hanged. Prisoners were stoned or thrown into the river with mill wheels around their necks. Simon de Montfort blinded and cut the noses off a hundred defenders of the castrum of Bram, leaving one of them one-eyed to guide the rest to the castrum of Cabaret, the centre of Occitan resistance. In 1210, while the crusaders were besieging Termes, the Occitans roamed the territory in order to capture them and sent them to Montfort's army after having gouged out their eyes and cut off

47 J. Gillingham, Crusading warfare, chivarly and the enslavement of women and children, in: The Medieval way of war. Studies in Medieval military history in honor of Bernard S. Bachrach, ed. G.I. Halfond, Aldershot 2015, p. 135.

${ }^{48}$ M. Prestwich, Edward I, Berkeley 1988, p. 471.

49 A. Macdonald, Two kinds of war?..., p. 220-221. The author is of the opinion that Edward had a perfect right to sack Berwick as its citizens refused to submit and, from his point of view, Scots deserved to be punished for defying their rightful lord. On the hand, Anne McKim observes that condemnation of Edward's actions at Berwick by contemporary chroniclers points to the fact that it was regarded as violation of unwritten laws of arms that codified limits on violence. A. McKim, Scottish national heroes and the limits of violence, in: A great effusion of blood? Interpreting Medieval violence, ed. M. Meyerson, D. Thiery, O. Falk, Toronto 2004, p. 134-135.

${ }^{50}$ A. Macdonald, Two kinds of war?..., p. 207. 
their noses or other members. During the sieges of Moissac (1212) and Beaucaire (1216) the Occitans killed and mutilated several prisoners, firing body parts from catapults in order "to terrify and outrage" the crusaders ${ }^{51}$.

The capture of Beziers by Montfort resulted in a massive butchery ended by fire. All the inhabitants who managed to escape massacre were burned. The whole city was annihilated in one afternoon ${ }^{52}$. This particularly merciless carnage was intended as an example of what would become to those daring to resist. The people of Lanquedoc were to be terrorised into submission ${ }^{53}$. After having taken Lavaur in 1211, Simon de Montfort burned 400 heretics and hanged 80 knights. The poet William of Tudela was dismayed at the treatment of lord Aimeri of Lavaur (who was hanged) and lady Girada, his sister, who was thrown down a well and stoned ${ }^{54}$.

The infamous massacre of Limoges, vividly described by Froissart as the aftermath of the siege, occurred in 1370 and has been traditionally attributed to the Black Prince. But was he really responsible for the merciless slaughter? Froissart wrote:

[...] all the others and their men burst into the city, followed by pillagers on foot, all in a mood to wreak havoc and do murder, killing indiscriminately, for those were their orders. There were pitiful scenes. Men, women and children flung themselves on their knees before the Prince, crying: "Have mercy on us, gentle sir!" But he was so inflamed with anger that he would not listen. Neither man nor woman was heeded, but all who could be found were put to the sword, including many who were in no way to blame. I do not understand how they could have failed to take pity on people who were too unimportant to have committed treason. [...] There is no man so hard-hearted that, if he had been in Limoges on that day, and had remembered God, he would not have wept bitterly at the fearful slaughter which took place. More than three thousand persons, men, women and children were dragged out to have their throats cut. May God receive their souls, for they were true martyrs ${ }^{55}$.

However, other contemporary sources, including a local chronicler of Limoges, and the Chandos Herald, who wrote an account of the prince's life, report a much smaller number of casualties (300) and do not claim that the majority of killed

${ }^{51}$ M. Alvira, Prisoners of war in the Albigensian Crusade, 1209-1229, "e-Stratégica", 1(2017), p. 269-284.

${ }^{52}$ M.G. PegG, A most holy war. The Albigensian Crusade and the battle for Christendom, New York 2008, p. 77.

${ }^{53}$ Ch. Tyerman, God's war. A new history of the crusades, Harvard 2006, p. 591. Yet Pierre des Vaux-de-Cernay, the contemporary chronicler, tried to justify the massacre by representing crusaders' violence as the instrument of justice sent to inflict punishment on the guilty citizens for their crimes. See E. Graham-Leigh, Justifying deaths. The chronicler Pierre des Vaux-de-Cernay and the massacre of Béziers, "Medieval Studies", 63(2001), p. 283-303.

${ }^{54}$ J. Gillingham, Crusading warfare..., p. 150.

55 Jean Froissart, Chronicles, sel., trans. and ed. G. Brereton, Penguin Books 1978, p. 178. 
were non-combatants ${ }^{56}$. Also Christine de Pizan, the contemporary biographer of Charles V, does not confirm Froissart's version, giving the number ca. 400 of those killed and captured, and not mentioning any massacre of civilians. The recently discovered Paris Parlement evidence tells a very different story of the sack of Limoges. As English troops entered the cité, the French garrison killed those inhabitants who had let them in and fired the houses. There was indeed a massacre (with hundreds, not thousands, of casualties) but it was carried out by the French, not the English. As transpires from the documents, the major part of Limoges (which was divided into two parts - the cite and the chateau) remained loyal to the English prince. What is more, the letters of the prince himself show that he did not blame the inhabitants of Limoges for the treason of their bishop ${ }^{57}$.

Spectrum of violence also included tournaments, although they were supposed to be entertaining. Early mêlée tournaments actually differed little from real warfare, especially when fought with sharp weapons - many knights suffered grave injuries or were killed ${ }^{58}$. A mêlée tournament was held in 1273 at Châlons between Edward I and his men on their way back to England from crusade, and Otto, Count of Châlons and later Count of Burgundy. The count threw his weapons and attacked Edward I seizing him around the neck in attempt to wrestle him from his horse. Edward resisted, and it was eventually the count who fell to the ground. The Burgundians, seeing their leader dismounted, retaliated, and the English engaged them in a bloody mêlée that resulted in numerous casualties. The count was forced to surrender. Because of abundant bloodshed, the chronicler Henry Knighton described the encounter as "non torniamentum sed parvum bellum de Chalons" 59 .

The list of mortalities in tournaments includes Henry II's son Geoffrey, Count of Brittany, who was killed in a tournament in France in 1186, Leopold, Duke of Austria, who was slain by a fallen horse in 1194, Gilbert Marshall, earl of Pembroke, killed in 1248, and many others. Tourneying could also result in severe disabilities ${ }^{60}$. Henry II banned tournaments in England around 1155, Edward III did the same in 1331. In France Charles IV had jousts and other deeds of arms explicitly banned ${ }^{61}$.

\footnotetext{
${ }^{56}$ M. Jones, The Black Prince, London 2017, p. 371.

${ }^{57}$ Ibidem, p. 368.

${ }^{58}$ See: R. BARBER, J. BARKer, Tournaments. Jousts, chivalry and pageants in the Middle Ages, Woodbridge 1989, p. 139-149; R.W. KAEUPER, Chivalry and violence in Medieval Europe, Oxford 1999, p. 164.

${ }^{59}$ M. Prestwich, Edward I..., p. 85; R.E. Whitbread, Tournaments, jousts and duels..., p. 114.

${ }^{60}$ J.R.V. BARKER, The tournament in England 1100-1400, Woodbridge 2003, p. 162.

${ }^{61}$ D. Crouch, Tournament, London 2005, p. 52.
} 
Attempts to restrain violence, though not particularly effective, were not confined to the Peace and Truce of God mentioned above. The kings tried to impose some order on their soldiers' activities which resulted in Ordinances or articles of war, promulgated for specific military deployments ${ }^{62}$. Edward III issued special Ordinances in 1346 for his campaign in France, partly aimed at protection of non-combatants who were threatened by troops ${ }^{63}$, and Richard II in 1385 for the expedition to Scotland. These regulations often emphasize the necessity of controlling pillage. They also explicitly identified the categories of people who had the status of non-combatants (commonly used medieval term was inermis unarmed): women, churchmen, religious, and anyone who does not carry arms ${ }^{64}$. Also Henry V, while engaged in the conquest of Normandy, made the point that non-combatants should be treated as prospective subjects, with their possessions not plundered ${ }^{65}$.

In 1417 Henry V issued disciplinary ordinances regulating the conduct of field $\operatorname{armies}^{66}$. He explicitly forbade setting fire and attacking churchmen and the defenceless:

${ }^{62}$ As Maurice Keen points out, it was codification of the old and well known martial customs, not the introduction of the new rules. M. Keen, Richard II's ordinances of war of 1385, in: Rulers and ruled in late Medieval England. Essays presented to Gerald Harris, ed. R.E. Archer, S. Walker, London 1995, p. 47.

${ }^{63}$ According to the Acta bellicosa, "The English king, feeling for the sufferings of the poor people of the country, issued an edict throughout the army, that no town or manor was to be burnt, no church or holy place sacked, and no old people, children or women in his kingdom of France were to be harmed or molested; nor were they to threaten people, or do any kind of wrong, on pain of life and limb. He also ordered that if anyone caught someone in the act of doing these or other criminal acts and brought him to the king, he should have a reward of forty shillings". Another chronicle, the Historia Rojfensis, gives a similar summary of Edward's actions, although it omits the ban on the burning of towns and manors and mentions specifically that those "who freely enter the king's peace" should not suffer any damage to themselves or their property. A. CURRY, Military ordinances of Henry $V$. Texts and contexts, in: War, government and aristocracy in the British Isles C.1150-1500..., p. 229.

${ }^{64} \mathrm{M}$. STRICKLAND, Rules of war or war without rules? Some reflections on conduct and the treatment of non-combatants in Medieval transcultural wars, in: Transcultural wars from the Middle Ages to the 21 st century, ed. H.-H. Kortüm, Berlin 2006, p. 109. However, non-combatants not always were passive, they often took arms trying to defend themselves.

${ }^{65}$ Of the twenty-six clauses in Richard II's ordinances, twenty-two are found in all four of the Henrician texts. These include protection of the church, churchmen, and women; obedience to the king, constable, marshal and captains; discipline within the host both on the march and in camp; rights in prisoners; and controls on the issue of safe-conducts. There are variations between Richard and Henry's ordinances but these relate either to modifications in punishments, or to clarification of issues, and do not change the meaning and intention of the clauses themselves. A. CurRY, Military ordinances of Henry V..., p. 230.

${ }^{66}$ As Maurice Keen observed, "for each new host [...] a new set of orders was needed". M. KeEN, Richard II's ordinances of war..., p. 35. 
The king had prudently issued, amongst other most worthy ordinances, a command to the army that under pain of death there should be no more setting fire to places, as there had been to begin with, and that churches and sacred buildings along with their property should be preserved intact, and that no one should lay hands on a woman or a priest or servant of a church, unless he happened to be armed, offered violence, or attacked anyone ${ }^{67}$.

Violence, however, could hardly be avoided in war. Basically, it could only be redirected or restrained to some extent. Kings' ordinances did little or nothing to achieve this aim. In spite of Edward's III efforts to check excesses by his troops, there was not much he could do - it was virtually impossible to restrain troops whose main object was plunder. Similarly, the raids of 1355-1356 were particularly violent and it seems that the Black Prince was unable to prevent a great deal of devastation, such as the burning of Carcassonne after he had given explicit orders for its preservation ${ }^{68}$.

Ravaging, taking spoils and booty was regarded as licit only in the course of properly sanctioned war. When the grande chevauchée authorised by the Black Prince had come to an end, his soldiers were to pay for provisions they had been taking freely during the raid. However, after the military campaign had ended the troops were all the harder to control. Even if non-combatants were not killed, they certainly were not protected either. It was not uncommon that garrisons attacked non-combatants they were supposed to protect $^{69}$.

Apart from royal ordonnances, the only restraint on violence could have been imposed by the chivalric sense of honour. Elevated ideals of chivalric code created the belief that knights were incapable of ignoble deeds ${ }^{70}$. Rules of chivalry included the protection of non-combatants and merchants coming with provisions. Regarded as immune of acts of war were clergy, students, pilgrims, women, children,

${ }^{67}$ Gesta Henrici Quinti..., p. 26-27. In 1419 in Henry's ordinances were added children, labourers, ploughmen, and merchants. A. CuRRY, Military ordinances of Henry V..., p. 226. Malcolm Vale maintains that Henry tried to restrain violence when he could. M. VALE, Henry $V$. The conscience of a king, New Haven 2016, p. 266 n.

${ }^{68}$ D. GreEn, The Black Prince..., p. 77. There were also other factors that contributed to violence restraint: one of them was greed resulting in the fear of losing the prisoner's ransom should he die. The second factor was the fear of retaliation. R. АмвüHL, Prisoners of war in the Hundred Years War. Ransom culture in the late Middle Ages, Cambridge 2013, p. 48.

${ }^{69}$ C. TAYLOR, Chivalry and the ideals..., p. 217.

${ }^{70}$ This belief, however, was not substantiated even by the Arthurian legends that set standards of chivalric behaviour - "The majority of the Round Table knights are unable to meet the standard imposed by Arthur's Pentecostal Oath and the expectations of chivalry custom. Instead, they tend to make gestures toward justice when it suits them, while feeling free to violate knightly principle in the interest of their own desires". Like real knights, they are inconsistent see L.K. BEDwELL, The flawed ideal. Justice and injustice in Malory's Morte Darthur, Waco 2011, p. 186-187. 
and peasants ${ }^{71}$. Sadly, chivalric ideals were not followed in real life - illegitimate acts of war and violent crimes were common experience. As Strickland points out, the nature of medieval warfare made the chivalric code inefficient in granting immunity to non-combatants ${ }^{72}$.

Although violence was not exactly approved, it could nevertheless be seen in a positive light if it served the right purpose. Violence could be an instrument of justice used to restore order and as such was opposed to cruelty regarded as despicable and unjust in both literary and historical sources ${ }^{73}$. Thomas of Marle, lord of Coucy and a former crusader, achieved notoriety due to his cruel behaviour. He terrorized the country torturing peasants and captives, beating then and starving to death. According to Guibert of Nogent, his cruelty was unheard of. As a result, Thomas was condemned in the Royal Court of France. What is more, he was proclaimed enemy of peace and excommunicated in 1114. Council of Beauvais, after having pronounced the sentence in Thomas' absence, deprived him of the knight's belt and divested him of his honors ${ }^{74}$.

The first of the chivalric scholars was Ramon Llull, the Majorcan knight, theologian and philosopher, writing in the second half of the thirteenth century. In his Book of the Order of Chivalry he outlined the duties of a knight and what he considered to be acceptable behaviour during times of war, stating that the primary duty of the knight was to maintain justice, to defend the Church and the Holy Catholic Faith, to protect his secular ruler, to defend the weak and peasants, to support widows, orphans and the helpless ${ }^{75}$. Nevertheless, Llull does not elaborate

${ }^{71}$ N. WRIGHT, Knights and peasants. The Hundred Years War in the French countryside, Woodbridge 1998, p. 28-30.

${ }^{72}$ M. StRickland, War and chivalry..., p. 335. Green observes: “[...] it is difficult to see those outside the chivalric order gaining any practical benefits from the code. For some, such as Henry of Grosmont, duke of Lancaster, chivalry prescribed a strict moral code and contemporaries saw him as an archetype of religious chivalry. He crusaded in Lithuania and elsewhere and was the author of a devotional treatise that confessed his own sins and highlighted the tension between one's duty as a Christian and a delight in the noble lifestyle. Nonetheless, on several occasions he massacred the inhabitants of a city who had resisted him, including women and children. His acts were justified by the Laws of War and did not detract from his chivalric status". D. GreEn, The Black Prince..., p. 76.

${ }^{73}$ The aspect of cruelty appeared when victims of violence were defenceless or when it was directed against the Church and its ministers. Cruelty in early medieval sources is criticised implicitly by describing perpetrators' behaviour as pagan: associating with paganism meant evil. D. BARAZ, Medieval cruelty. Changing perceptions, late antiquity to the early modern period, New York 2003, p. $50 \mathrm{n}$.

${ }^{74}$ A. Grabois, Militia and malitia. The Bernardine visions of chivarly, in: The Second Crusade and the Cistercians, ed. M. Gervers, New York 1992, p. 53.

${ }^{75}$ Ramon Llull, The book of the Order of Chivalry, trans. N. Fallows, Woodbridge 2013, p. 50-51. See this topic: A. Niewiński, Ideat etosu rycerza w "Libro del orden de caballeria" Ramona Llulla, "Roczniki Humanistyczne", 66(2018), z. 2: Historia, p. 5-24. 
on the subject of treating prisoners or non-combatant immunity, apart from stating that the knight should "take pity on the helpless and be merciful to the vanquished who begs for mercy"76.

Geoffrey de Charny, regarded as the most worthy and valiant, a quintessential knight of his age, in his Book of Chivalry criticized knights who "murder others in a bad cause" or "commit a treacherous deed by seizing, plundering, and robbing others without any challenge and without any wrongdoing on the part of the persons attacked" "77. Yet, he was not especially concerned with mitigating knights' brutal behaviour ${ }^{78}$. He values prowess and courage of men-at-arms who "are able to make war on, inflict damage on and win profit from their enemies" all of which requires strenuous effort which is laudable ${ }^{79}$. Winning the battle should come first, knights cannot be too intent on plundering, prisoners or booty. De Charny, however, was far more preoccupied with knights' skills in performing deeds of arms and the resulting glory than with non-combatant's fate ${ }^{80}$.

Indeed, given the character of his occupation, a knight's prowess and fighting ability was of primary importance. Kaeuper defines prowess as "the will, sheer strength and endurance and actual physical capacity with edged weapons by which one knight completely dominates another" ${ }^{\prime \prime 1}$. A knight was first of all an armed man and could make use of his weapon to oppress the weaker in order to gain advantage over the enemy. Acts of violence and destruction were quiet often glorified in chivalric literature and chronicles in order to emphasise the bravery and strength of the warriors ${ }^{82}$.

The legitimacy of violence was also discussed by Honoré Bouvet, a Benedictine monk writing in the fourteenth century, and Christine de Pizan, an early fifteenth-century court writer. They advocated the idea that certain groups of people should be immune from war because of their social function (e.g. clerics, farmers,

${ }^{76}$ RAMON LLuLL, The book of the Order of Chivalry..., p. 72.

77 The book of chivalry of Geoffroi de Charny, ed. R.W. Kaeuper, E. Kennedy, Philadelphia 1996, p. 179.

${ }^{78}$ For violence as an inherent component of chivalric ethos see R. KAEUPER, Chivalry and violence...

${ }^{79}$ The book of chivalry..., p. 99.

${ }^{80}$ A. Niewiński, Rycerskie ideały codziennego życia wedtug "Ksiegi o rycerstwie" Godfryda de Char$n y$, "Acta Universitatis Lodziensis. Folia Historica", 101(2018), p. 11-28.

${ }^{81}$ R. KAEUPER, Chivalry and violence..., p. 25.

${ }^{82}$ The paragons of chivalry often displayed considerable violence: Richard Marshal (second son of the famous William) with one mighty stroke cut off both hands of the man reaching for his helmet in a close encounter. With an even mightier blow he cut a knight down to the navel. Robert Bruce's most noted feat of prowess was to split the head of Henry de Bohun at the beginning of the battle of Bannockburn. Joinville admires three fine blows delivered by a Genoese knight in an expedition to Jaffa: one enemy is run through with a lance, one's head is sent flying off into the field, one lance-wielding enemy arm is cut off with a swift back-handed sword stroke, after dodging the foe's lance. R. KAEUPER, Chivalry and violence..., p. $141 \mathrm{n}$. 
merchants). They should live in peace, as long as they are doing their work and do not engage themselves in acts of war.

\begin{abstract}
Ox-herds, and all husbandmen, and ploughmen with their oxen, when they are carrying on their business, and equally when they are going to it or returning from it, are secure, according to the written law, and neither emperor, king, duke nor count, nor any person whatsoever can excuse himself from keeping this law. It is also "a very terrible act of war" to attack a foreign student, his servants, his father or his brother who attend or visit him; It is also forbidden under any circumstance to lay violent hands on the infirm and the insane; on the very old and the very young; on ambassadors, on clerks and on pilgrims; All these categories of people are entitled by their very status to the highest and most binding safe conduct of all: namely, the "safeguard of the Holy Father of Home"; The infringement of such a security is a mortal sin and may be punished by excommunication ${ }^{83}$.
\end{abstract}

Ox-herds and ploughmen, those who plough and cultivate the soil were to be spared, since other people sustenance depended on their labour. Soldiers and clergy had a choice, they could travel, they did not have to produce food and generally were in a better situation than peasants who could not do anything but suffer from maltreatment. Once the war was declared, both sides were free to use any means to do harm to their opponent; as an unavoidable consequence, non-combatants lost their goods and suffered harm ${ }^{84}$.

Bouvet accepted that captives could be imprisoned and held in chains, but he firmly condemned cruel treatment and torture of prisoners in order to induce them to pay higher ransom (which appears to have been practiced). What is more, he claimed that mistreatment would free a prisoner from the oath of surrender ${ }^{85}$.

Protection of non-combatants and prisoners of war were also the matter of concern for Christine de Pizan. She argued that prisoners could be reduced to slavery but, once captured, they should not be killed ${ }^{86}$. Prisoner is allowed not to keep his oath if it was extracted from him by force and under threat, but should not be excused from paying ransom if captured in a proper way ${ }^{87}$. She also strongly objected

${ }^{83}$ The tree of battles..., p. 189.

84 "But if on both sides war is decided upon and begun by the Councils of the two kings, the soldiery may take spoil from the kingdom at will, and make war freely; and if sometimes the humble and innocent will suffer harm and lose their goods, it cannot be otherwise; [...] Valiant men and wise, however, who follow arms should take pains, so far as they can, not to bear hard on the simple and innocent folk but only on those who make and continue war and flee peace". Ibidem, p. 155.

${ }^{85}$ C. TAYLOR, Chivalry and the ideals..., p. 204.

${ }^{86}$ Christine de Pizan, The book of deeds of arms and of chivalry, ed. and trans. C.C. Willard, S. Willard, Pennsylvania 1999, p. 169.

${ }^{87}$ Ibidem, p. 182-183. See this topic: A. Niewiński, Jeniectwo wojenne w późnym średniowieczu. Studia nad problematyka zjawiska w Polsce w kontekście zachodnioeuropejskim, Lublin 2015, p. 183 n. 
to mistreatment and killing of non-combatants who do not participate in military activities:

I ask you whether a king or prince [...], even though the war may be just, has the right to overrun the enemy land and take prisoner all manner of people, including common people, that is peasants, shepherds and such like; it would appear not. Why should they bear the burden of the profession of arms, of which they know nothing? [...] common people are not called on to bear arms; rather it is distasteful to them, for they say they want to live in peace and ask no more. They should be free, it seems, to me, just as all priests and churchmen are, because their estate is outside military activity. What honor can accrue to a prince in killing, overrunning or seizing people who never have born arms nor could make use of them, or poor innocent people who do nothing but till the land and watch over animals? ${ }^{88}$

The common people should be granted immunity, unless they actively engaged themselves in combat or assisted the enemy. Their involvement of arms can be permitted only in self-defence.

As numerous examples abundantly demonstrate, the Middle Ages were characterised by widespread and unrestricted violence, carried out everywhere on any scale possible. The remedial measures were attempted firstly by the peace movements promoted by Church in the 11th century. Later on canon lawyers and other writers undertook an effort to set limitation to excessive violence by regulating conduct of arm hostilities according to the principles of ius in bello and defining the status of non-combatants and prisoners of war. Royal military ordinances were intended to impose order and control over troops' behaviour and the code of chivalry was to outline the limits of morally acceptable military practice. In real life, however, all these efforts had relatively limited applicability. As Kaeuper points out:

Chivalry brought no radical transformation in medieval warfare, as it touched the population as a whole; above all, it imposed no serious check on the looting, widespread destruction, and loss of non-combatant lives that seem to have been the constant companions of warfare. [...] As a code, chivalry had next to nothing to do with ordinary people at all ${ }^{89}$.

${ }^{88}$ Ibidem, p. 171.

${ }^{89}$ R. KAEUPER, Chivalry and violence..., p. 185. 


\section{BIBLIOGRAPHY}

\section{SOURCES}

Albert of Aachen, Historia Ierosolimitana. History of the journey to Jerusalem, ed. and trans. S.B. Edgington, Oxford 2007.

The book of chivalry of Geoffroi de Charny, ed. R.W. Kaeuper, E. Kennedy, Philadelphia 1996.

Christine de Pizan, The book of deeds and arms and of chivalry, ed. and trans. C.C. Willard, S. Willard, Pennsylvania 1999.

The chronicle of Jean de Venette, ed. and trans. J. Birdsall, R.A. Newhall, New York 1953

La chronique d'Enguerran de Monstrelet, t. 3, ed. L. Douët-d'Arcq, La Société de l'histoire de France, 1859.

Contemporary chronicles of the Hundred Years' War, ed. and trans. P.E. Thompson, London 1966.

Gesta Henrici Quinti. The deeds of Henry the Fifth, ed. F. Taylor, J.S. Roskell, Oxford 1975.

Jean Froissart, Chronicles, sel., trans. and ed. G. Brereton, Penguin Books 1978.

JeAn JuvÉnAl des Ursins, Histoire de Charles VI, roy de France, in: Nouvelle collection des mémoires pour servir à l'histoire de France, vol. 2, ed. J.F. Michaud, J.J.F. Poujoulat, 1st series, Paris 1836. Ramon Llull, The book of the Order of Chivalry, trans. N. Fallows, Woodbridge 2013.

The Tree of Battles of Honoré Bonet, trans. and ed. G. W. Coopland, Liverpool, 1949.

The wars of Edward III. Sources and interpretations, ed. and introduction C.J. Rogers, Woodbridge 1999.

\section{LITERATURE}

The age of the Hundred Years War, ed. C.J. Rogers, K. DeVries, J. France, Woodbridge 2009 (Journal of Medieval Military History, 7).

Agincourt in context. War on land and sea, ed. R. Ambühl, C. Lambert 2018.

Allmand Ch., The 'De re militari' of Vegetius. The reception, transmission and legacy of a Roman text in the Middle Ages, Cambridge 2011.

Alvira M., Prisoners of war in the Albigensian Crusade, 1209-1229, "e-Stratégica”, 1(2017), p. 269-284.

Амвӥнl R., Prisoners of war in the Hundred Years War. Ransom culture in the late Middle Ages, Cambridge 2013.

Arab historians of the crusades, ed. F. Gabrieli, New York 1993.

Baha ad-Din, Massacre of the Muslim prisoners, in: Arab historians of the crusades, selection and translation F. Gabrieli, New York 1993.

BARAZ D., Medieval cruelty. Changing perceptions, late antiquity to the early modern period, New York 2003.

BARber R., BARKer J., Tournaments. Jousts, chivalry and pageants in the Middle Ages, Woodbridge 1989.

BARKER J.R.V., The tournament in England 1100-1400, Woodgridge 2003.

Bedwell L.K., The flawed ideal. Justice and injustice in Malory's Morte Darthur, Waco 2011.

Bellamy A.J., Just wars. From Cicero to Iraq, Cambridge 2006.

Bellamy J.G., The law of treason in England in the later Middle Ages, Cambridge 2004. 
Brooks R., The knight who saved England. William Marshal and the French invasion, 1217, Bloomsbury 2014.

Crouch D., Tournament, London 2005.

Crouch D., William Marshal. Knighthood, war and chivalry, 1147-1219, Routlege 2014.

Crusaders, condottieri, and cannon. Medieval warfare in societies around the Mediterranean, ed. L.J. Andrew Villalon, D. Kagay, Leiden 2002.

Curry A., Agincourt. A new history, Stroud 2005.

CURry A., The battle of Agincourt. Sources and interpretations, Woodbridge 2000.

Curry A., Military ordinances of Henry V. Texts and contexts, in: War, government and aristocracy in the British Isles C.1150-1500. Essays in honour of Michael Prestwich, ed. Ch. Given-Wilson, A. Kettle, L. Scales, Woodbridge 2008, p. 214-250.

DeVries K., The effect of killing the Christian prisoners at the battle of Nicopolis, in: Crusaders, condottieri, and cannon. Medieval warfare in societies around the Mediterranean, ed. L.J. Andrew Villalon, D. Kagay, Leiden 2002, p. 157-172.

DeVries K.L., The lack of a western European military response to the Ottoman invasions of Eastern Europe from Nicopolis (1396) to Monies (1526), in: Medieval warfare 1300-1450, ed. K.L. DeVries, Ashgate 2010, p. 417-440.

Friedman Y., Encounter between enemies. Captivity and ransom in the Latin Kingdom of Jerusalem, Leiden 2002.

Gilchrist J., The Papacy and war against the 'Saracens', 795-1216, "The International History Review”, 10(1988), No. 2, p. 174-197.

Gillingham J., Crusading warfare, chivarly and the enslavement of women and children, in: The Medieval way of war. Studies in Medieval military history in honor of Bernard S. Bachrach, ed. G.I. Halfond, Aldershot 2015, p. 133-152.

Gillingham J., Richard I, New Haven 1999.

Gouveia Monteiro J., The battle of Aljubarrota [1385]. A reassessment, in: The age of the Hundred Years War, ed. C.J. Rogers, K. DeVries, J. France, Woodbridge 2009 (Journal of Medieval Military History, 7), p. 75-103.

Grabors A., Militia and malitia. The Bernardine visions of chivarly, in: The Second Crusade and the Cistercians, ed. M. Gervers, New York 1992, p. 49-56.

Graham-Leigh E., Justifying deaths. The chronicler Pierre des Vaux-de-Cernay and the massacre of Béziers, "Medieval Studies", 63(2001), p. 283-303.

Gransden A., Historical writing in England c. 1307 to the early sixteenth century, London 1982.

A great effusion of blood? Interpreting Medieval violence, ed. M.D. Meyerson, D. Tiery, O. Falk, Toronto 2004.

Green D., The Black Prince, Stroud 2008.

GreEn D., The Hundred Years War. A people's history, New Haven 2014.

Hewitt H.J., The Black Prince's expedition of 1355-1357, Manchester 1958.

HosLer J.D., The Siege of Acre, 1189-1191. Saladin, Richard the Lionheart, and the battle that decided the Third Crusade, Yale 2018.

JoHnson J.T., Just war tradition and the restraint of war. A moral and historical inquiry, Princeton 2014 JoNES M., The Black Prince, London 2017.

KaEUPer R.W., Chivalry and violence in Medieval Europe, Oxford 1999. 
KeEn M., The Laws of war in the late Middle Ages, London 1965.

KeEn M., Richard II's ordinances of war of 1385, in: Rulers and ruled in late Medieval England. Essays presented to Gerald Harris, ed. R.E. Archer, S. Walker, London 1995, p. 33-48.

Killing and being killed. Bodies in battle. Perspectives on fighters in the Middle Ages, ed. J. Rogge, Bielefeld 2017.

KING A., "Then a great misfortune befell them". The laws of war on surrender and the killing of prisoners on the battlefield in the Hundred Years War, in: Agincourt in context. War on land and sea, ed. R. Ambühl, C. Lambert 2018, p. 106-117.

KIng A., War and peace. A knight's tale. The ethics of war in Sir Thomas Gray's Scalacronica, in: War, government and aristocracy in the British Isles, C.1150-1500. Essays in honour of Michael Prestwich, ed. Ch. Given-Wilson, A. Kettle, L. Scales, Woodbridge 2008, p. 148-162.

The laws of war. Constraints on warfare in the western world, ed. M. Howard, G.J. Andreopoulos, M.R. Shulman, New Haven 1994.

Macdonald A.J., Two kinds of war? Brutality and atrocity in later Medieval Scotland, in: Killing and being killed. Bodies in battle. Perspectives on fighters in the Middle Ages, ed. J. Rogge, Bielefeld 2017, p. 199-230.

MacInnes I.A., Scotland's second war of independence 1332-1357, Cambridge 2016.

MсKIм A., Scottish national heroes and the limits of violence, in: A great effusion of blood? Interpreting Medieval violence, ed. M.D. Meyerson, D. Tiery, O. Falk, Toronto 2004, p. 131-143.

McLynn F., Lionheart and Lackland. King Richard, king John and the wars of conquest, London 2006.

Marvin L.W., Atrocity and massacre in the high and late Middle-Ages, in: Theatres of violence. Massacre, mass killing and atrocity throughout history, ed. Ph. Dwyer, L. Ryan, New York-Oxford 2015, p. 50-62.

Medieval warfare 1300-1450, ed. K.L. DeVries, Ashgate 2010.

The Medieval way of war. Studies in Medieval military history in honor of Bernard S. Bachrach, ed. G.I. Halfond, Aldershot 2015.

NiEwiŃSKi A., Ideat etosu rycerza w "Libro del orden de caballeria" Ramona Llulla, "Roczniki Humanistyczne", 66(2018), z. 2: Historia, p. 5-24.

NiewiŃski A., Jeniectwo wojenne w późnym średniowieczu. Studia nad problematyka zjawiska w Polsce w kontekście zachodnioeuropejskim, Lublin 2015.

NiEwIŃsKi A., Rycerskie ideały codziennego życia wedlug "Księgi o rycerstwie" Godfryda de Charny, "Acta Universitatis Lodziensis. Folia Historica", 101(2018), p. 11-28.

The original chronicle of Andrew of Wyntoun, vol. 6, ed. F.J. Amours, Scottish Text Society 1903-1914. Pegg M.G., A most holy war. The Albigensian Crusade and the battle for Christendom, New York 2008. Prestwich M., Edward I, Berkeley 1988.

Riley-Smith J., The crusades. A history, New Haven 2005.

Rulers and ruled in late Medieval England. Essays presented to Gerald Harris, ed. R.E. Archer, S. Walker, London 1995.

Russell F.H., The just war in the Middle Ages, Cambridge 1975.

The Second Crusade and the Cistercians, ed. M. Gervers, New York 1992.

Sмiтн T.R., Willing body, willing mind. Non-combatant culpability according to English combatant writers 1327-77, in: Killing and being killed. Bodies in battle. Perspectives on fighters in the Middle Ages, ed. J. Rogge, Bielefeld 2017, p. 79-107. 
Stacey R.C., The age of chivalry, in: The laws of war. Constraints on warfare in the western world, ed. M. Howard, G.J. Andreopoulos, M.R. Shulman, New Haven 1994, p. 27-39.

STRICKLAND M., Rules of war or war without rules? Some reflections on conduct and the treatment of non-combatants in Medieval transcultural wars, in: Transcultural wars from the Middle Ages to the 21st century, ed. H.-H. Kortüm, Berlin 2006, p. 107-140.

StRICKLAND M., War and chivalry. The conduct and perception of war in England and Normandy 1066-1217, Cambridge 1996.

STROIK J., The massacre at Acre - mark of a bloodthirsty king?, "Oshkosh Scholar”, 5(2010), p. 29-35.

TAYLOR C., Chivalry and the ideals of knighthood in France during the Hundred Years War, Cambridge 2013.

Theatres of violence. Massacre, mass killing and atrocity throughout history, ed. Ph. Dwyer, L. Ryan, New York-Oxford 2015.

Transcultural wars from the Middle Ages to the 21st century, ed. H.-H. Kortüm, Berlin 2006.

Tyerman Ch., God's war. A new history of the crusades, Harvard 2006.

Vale M., Henry $V$. The conscience of a king, New Haven 2016.

VAN EICKeLs K., Gendered violence. Castration and blinding as punishment for treason in Normandy and Anglo-Norman England, "Gender \& History", 16(2004), No. 3, p. 588-602.

War, government and aristocracy in the British Isles C.1150-1500. Essays in honour of Michael Prestwich, ed. Ch. Given-Wilson, A. Kettle, L. Scales, Woodbridge 2008.

WheatLey E., Stumbling blocks before the blind. Medieval constructions of a disability, Michigan 2014.

Whetham D., Just wars and moral victories. Surprise, deception and the normative framework of European war in the Later Middle Ages, Leiden 2009.

WhitBread R.E., Tournaments, jousts and duels. Formal combats in England and France, circa 13801440, University of York 2013.

Wright N., Knights and peasants. The Hundred Years War in the French countryside, Woodbridge 1998.

\author{
INTER ARMA ENIM SILENT LEGES \\ (W CZASIE WOJNY MILCZĄ PRAWA) \\ PRZEMOC W ŚREDNIOWIECZNEJ WOJNIE
}

Streszczenie. Niniejszy artykuł porusza temat przemocy podczas działań wojennych w wiekach średnich. Średniowieczni kronikarze i pisarze podają liczne przykłady okrucieństw i masakr dokonywanych podczas konfliktów zbrojnych na jeńcach i osobach niebiorących udziału w walkach. Już w XI wieku Kościół podejmował pierwsze próby nałożenia ograniczeń na sposób prowadzenia wojen. W przedstawionym tekście zbadano, czy wysiłki te (wraz z kodeksem rycerskim, rozporządzeniami królewskimi i pismami na temat ius in bello) wpłynęły na zachowanie żołnierzy i przyczyniły się do zmniejszania cierpień cywili. Ostatecznie stwierdzono, że zasadniczo nie przyniosły oczekiwanych rezultatów.

Słowa kluczowe: przemoc, działania wojenne, średniowiecze, ius in bello, jeńcy wojenni 